\title{
Diseminasi Model Perlindungan Hak Kekayaan Intelektual Produk Kain Organik pada Komunitas Kahut Sigerbori di Labuhan Ratu Bandar Lampung
}

\author{
Ria Wierma Putri, Rehulina, Abdul Muthalib Tahar, Naek Siregar* \\ Hubungan Internasional, Universitas Lampung, Bandar Lampung, 35145, Lampung, Indonesia
}

\begin{abstract}
.
Gerakan mempromosikan produk lokal dan ramah lingkungan meningkat seiring dengan meningkatnya kesadaran masyarakat untuk lebih menjaga lingkungan. Salahsatu usaha lokal di Bandar Lampung yang mendukung prinsip ramah lingkungan adalah Kahut Sigerbori yang merupakan usaha kain dengan pewarnaan alami dan organik bahkan motif shibori menggunakan flora alami. Pertumbuhan usaha lokal yang ramah lingkungan mendorong persaingan antar para usahawan sehingga mereka harus meningkat kreativitas dan kekhasan produk masing masing. Kekhasan produk menjadi nilai tambah yang akan meningkatkan nilai produk tersebut. Tetapi kekhasan ini juga dapat membuka peluang ketertarikan usahawan lain untuk meniru design, menggunakan merek yang sama tanpa izin ataupun membuat produk yang mirip. Kecurangan ini dapat dicegah apabila pemilik asli melakukan perlindungan terhadap produk ciptaannya yaitu Perlindungan hak kekayaan intelektual (HAKI). Namun terkadang pemilik tidak memahami bagaimana cara memperoleh perlindungan tersebut, mengetahui namun berpikir prosedurnya akan sangat rumit atau tidak memahami secara pasti bentuk HAKI yang tepat untuk produk usahanya. Terutama apabila berkaitan dengan metode tradisional, dilakukan oleh grup dan bukan merupakan pencipta pertama. Permasalahan ini sering dialami oleh para usahawan yang bergerak dibidang kerajina seperti halnya komunitas Kahut Sigerbori. Ada beberapa opsi yang dapat diterapkan untuk melindungi HAKI bagi produk kerajinan tangan Kahut Sigerbori dengan melihat tiap elemen elemen yang dapat dilindungi seperti design dilindungi hak cipta, tehnik pewarnaan dan pemotifan dengan perlindungan pengetahuan tradisional, organisme yang digunakan dapat dilindungi dengan sumber daya genetic serta dapat dimungkinkan apabila produk tersebut menggunakan bahan dari daerah geografis tertentu maka dapat dilindungi indikasi geografis bahkan paten jika terdapat inovasi baru.
\end{abstract}

\section{Keywords.}

kain lokal, pewarnaan alami, hak cipta, pengetahuan tradisional, sumber daya genetic, indikasi geografis.

\section{* Corresponding author: naeksiregar@yahoo.com}

Received 20 October 2021; Received in revised form 30 October 2021; Accepted 2 November 2021 


\section{PENDAHULUAN}

Kahut Sigerbori adalah usaha shibori atau batik tulis dengan pewarnaan alami menggunakan tehnik pounding atau pukul. Kahut Sigerbori bernaung dibawah Koperasi Cinta Crafter Bandar Lampung salah satu koperasi khusus kerajinan tangan untuk mewadahi integrasi pengembangan UMKM kerajinan tangan Lampung serta menjadi sarana meningkatkan mutu pelaku usaha. Shibori merupakan kerajinan batik tulis yang biasanya menggunakan dua tehnik untuk membuat ecoprint.

\section{Metode Kukus/Steam/Hapazome}

Prinsip pewarnaan ecoprint metode ini adalah pencapan yang dilakukan secara langsung pada sumber zat warna (daun kersen) pada bahan tekstil dengan bantuan uap panas untuk mempercepat proses pewarnaannya. Dalam memperoleh warna yang sempurna dengan metode ini digunakan pula zat fiksasi berupa tawas tunjung dan kapur untuk memunculkan warna hasil reaksi dari uap panas, zat fiksasi dan klorofil daun kersen. Metode kukus dilakukan dengan mengukus tahap 1 bahan tekstil yang terdapat daun di dalam gulungannya selama selama 30 menit kemudian dilakukan pencelupan zat fiksasi dan terakhir dilakukan pengukusan tahap 2 yang bertujuan untuk memperkuat hasil warna. Pengukusan tahap 2 dilakukan selama 30 menit.

\section{Metode Pukul/Pounding}

Prinsip pewarnaan teknik ecoprint juga masih sama dengan metode kukus/steam. Akan tetapi perbedaannya pada metode pukul proses mengeluarkan ekstrak warna dilakukan dengan cara dipukul dengan benda keras seperti ulegan kayu untuk memindahkan zat warna dari sumber warna (daun kersen). Setelah dilakukan pemukulan secara merata pada seluruh permukaan daun, kain yangsudah terdapat zat warna didiamkan sebentar dan langsung di celupkan ke dalam zat fiksasi. Keunggulan metode pukul/pounding dari metode kukus yaitu area putih dari bahan tekstil yang tidak dikehendaki zat warna lebih bersih. Proses pemukulan dilakukan dengan dialasi kertas koran dan HVS serta bagian atas dialasi plastik.

Menurut ibu Anggraini, tehnik ini yang paling kuno, ramah lingkungan dan sederhana. Kahut Shibori fokus pada kerajinan handmade terutama pada batik tulis dan sulam pita. Sebagai usahawan beliau dituntut untuk selalu kreatif untuk menciptakan desain desain baru sehigga beliau berharap bahwa orang lain tidak akan meniru dan mengakui ciptaannya namun di satu sisi beliau tidak bisa mencegah apabila orang lain menggunakan tehnik yang sama. Istilah perlindungan HAKI sudah mulai familiar terdengar namun hanya berkaitan dengan merek dan paten itupun tidak paham prosedurnya, sedangkan bentuk HAKI yang lain belum terdiseminasi. Usahawan juga biasanya tidak memahami bentuk HAKI yang mana dengan usahanya terutama apabila berkaitan dengan ciptaan, penemuan, pengetahuan, tehnik dan bahan tradisional yang tidak diketahui siapa yang pertama kali menggunakan atau menciptakan. Untuk itu pengabdian ini akan memetakan, menyampaikan dan mendiskusikan model perlindungan hukum hak kekayaan intelektual untuk usaha batik tulis atau shibori.

Produk batik tulis sebagai karya ciptaan manusia dapat dilindungi dengan rezim HAKI. HAKI mulai diperkenalkan pada abad 1800an sebagai tuntutan untuk meningkatkan nilai tambah produk revolusi industry. Sehingga individu pencipta dapat meraih keuntungan ekonomi. Prinsip utamanya adalah diberikan kepada individu yang pertama kali mendaftarkan oleh karena itu pada awalnya kelompok individu tidak dapat mendaftar HAKI. 
HAKI pada perkembangannya tidak hanya mengakui hak intelektual indidividu namun juga mengakui adanya hak kekayaan intelektual komunal. Pengakuan terhadap hak kekayaan intelektual komunal awalnya diatur di Konvensi UNESCO 2003 yang mengatur warisan budaya tak benda adalah berbagai praktek, representasi, ekspresi, pengetahuan, keterampilan serta instrumen-instrumen, obyek, artefak dan lingkungan budaya yang terkait meliputi berbagai komunitas, kelompok, dan dalam beberapa hal tertentu, perseorangan yang diakui sebagai bagian warisan budaya mereka.

\section{Permasalahan Mitra}

Kahut Sigerbori adalah usaha batik tulis dengan menggunakan pewarnaan kain alami, motif flora dan metode pounding. Tehnik, bahan dan metode usaha yang digunakan oleh Kahut Sigerbori banyak digunakan oleh usahawan lain bahkan pemilik Kahut Sigerbori mentransfer pengetahuannya kepada orang lain. Namun kreatifitas dan keunikan produk Kahut Sigerbori tetap harus dilindungi untuk itu Kahut Sigerbori harus menemukan metode yang tepat untuk melindungi kreativitasnya namun tetap dapat berbagi ilmu dengan masyarakat. Perlindungan HAKI merupakan salahsatu opsi terbaik mengingat beberapa kondisi khas Kahut Sigerbori seperti tidak diketahui siapa yang pertama kali menciptakan tehnik pounding, menentukan bahan dan metode pewarnaan, dilakukan oleh komunitas dan untuk kepentingan bersama. Fakta fakta yang pada dasarnya bersebrangan dengan prinsip utama HAKI yaitu siapa yang mendaftar kali akan menjadi pemilik HAKI, dimiliki perorangan dan batasan waktu perlindungan.

\section{Diskusi}

Solusi

Melalui pemaparan materi, pemetaan bentuk bentuk HAKI dan diskusi berkenaan dengan elemen elemen khas Kahut Sigerbori maka dapat dikemukakan sebagai berikut:

a) Desain motif dengan menggunakan flora yang dilakukan bu Anggara Kumala Sari sebagai pekerja kreatif (pemilik Kahut Sigerbori) dapat dilindungi dengan hak kekayaan intelektual.

b) Produk Kahut Sigerbori walaupun desain motifnya original namun memiliki elemen elemen khas seperti:

1. tidak diketahui siapa yang pertama kali menciptakan tehnik hapazome

2. tidak jelas yang pertama kali menentukan bahan dan metode pewarnaan,

3. dilakukan oleh komunitas dan untuk kepentingan bersama

Perlindungan Hak kekayaan intelektual bagi produk organic Kahut Sigerbori dapat dilakukan melalui beberapa opsi model yaitu:

1. desain motif flora dilindungi dengan hak cipta

2. merek dagang kahut sigerbori dilindungi dengan merek

3. pengetahuan berkenaan dengan tehnik hapazome, tehnik pewarnaan dan peentuan bahan dapat dilindungi dengan rezim pengetahuan tradisional. Namun pengabdian ini difokuskan pada Perlindungan Merek dan Hak Cipta bagi produk Kahut Sigerbori.

\section{METODE PELAKSANAAN}

Metode dan Tahapan Kegiatan 
Kegiatan mengenai perlindungan hak kekayaan intelektual untuk produk komunitas Kahut Sigerbori dilakukan dengan menggunakan metode pemaparan materi, pembuatan poster pemetaan bentuk HAKI yang sesuai dan diskusi prosedur pendaftaran sesuai dengan jadwal waktu yang telah ditetapkan. Pada awal dilakukan pre-test dalam bentuk tanya jawab untuk mengetahui sejauh mana tingkat pemahaman mengenai hak kekayaan intelektual dan materi yang telah disampaikan. Pada akhir kegiatan dilakukan post-test melalui metode tanya jawab untuk mengetahui sejauh mana tingkat pemahaman mengenai hak kekayaan intelektual dan materi yang telah disampaikan dan enentukan opsi perlindungan HAKI yang dapat dipilih.

\section{Pelaksanaan Diseminasi}

Sebelum menjelaskan perihal pelaksanaan pengabdian yang dilakukan pada Kahut Sigerbori, perlu diuraikan terlebih dahulu mengenai beberapa tahapan pelaksanaan kegiatan pengabdian ini, yaitu pelasanaan diseminasi dan Focus Group Discussion. Pelasanaan kegiatan diseminasi kali ini sedikit berbeda dengan tahun lalu oleh karena pandemic covid 19 yang mengharuskan setiap pelaksanaan kegiatan mematuhi protocol Kesehatan. Sehingga peserta dibagi menjadi dua bagian dan dilaksanakan secara offline atau onsite dengan kunjungan langsung ke Komunitas Kahut Sigerbori dan sebagian di minta menyaksikan proses diseminasi melalui media streaming yaitu ZOOM meeting dengan ID meting 2640371020 dan passcode unila2020. Peserta offline berjumlah 20 Orang dan jumlah peserta online berjumlah 25 orang sehingga total peserta menjadi 45 orang. Selain Komunitas Kahut Sigerbori, diseminasi ini dihadiri oleh 2 UMKM (Usaha Mikro Kecil dan Menengah) lain yaitu Emma Apple's Handmade dan Lampung Ethnic yang bergerak di bidang usaha kerajinan tangan.

Kemudian, mengenai substansi dalam diseminasi, materi utama pada diseminasi ini adalah Perlindungan Kekayaan Intelektual dan prosedur permohonan pendaftarannya. Pada perencanaan pelaksanaan diseminasi diajukan model perlindungan hukum kekayaan intelektual merek (HAKI). Untuk itu dijabarkan berkenaan dengan gambaran umum perlindungan HAKI untuk produk kain organik, pengaturan perlindungan produk kain organik, syarat pendaftaran merek dan prosedur pendaftaran merek.

\section{Gambaran Umum Perlindungan Hak Kekayaan Intelektual Untuk Produk Kain Organik}

Pada dasarnya Hak Kekayaan Intelektual (HKI) muncul sebagai akibat adanya kepemilikan atas ide atau gagasan terhadap benda berupa informasi, ilmu pengetahuan, teknologi, seni, dll yang menimbulkan suatu hak milik yang tidak dapat diganggu gugat oleh siapapun. Adapun ruang lingkup hak-hak yang tercakup dalam perlindungan HKI berdasarkan Hasil-hasil Perjanjian Putaran Uruguay pada Negosiasi Perdagangan Multilateral Annec 1 C adalah (a) Hak Cipta; (b) Merek; (c) Indikasi Geografis; (d) Desain Industri; (e) Paten; (f) Layout Design. Kepemilikan HKI sangat penting dalam menghadapi pasar global, karena dengan kepemilikan HKI seseorang telah memiliki kepastian hukum atas produk yang dipasarkan [1-9].

Negara Indonesia memiliki kerajinan produk yang unik dan original dari berbagai daerah, termasuk Provinsi Lampung. Selain kain tapis, lampung memiliki kain yang pembuatannya dapat dikatakan sangat unik karena menggunakan teknik hapazome, yaitu seni olah kain menggunakan bahan-bahan alami seperti dedaunan dan bunga, kain ini dikenal dengan nama kahut sigerbori. 


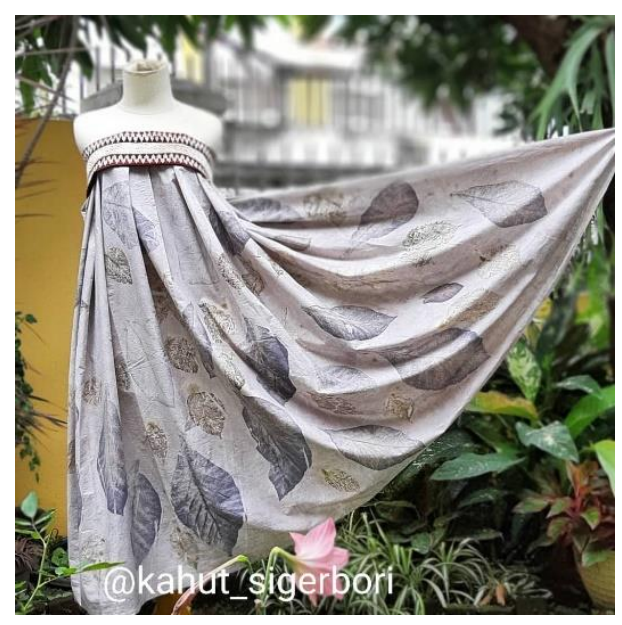

Gambar 1. Produk Kain Motif Kahut Sigerbori

Kahut sigerbori memiliki kekhasan pada motif, teknik pembuatan dan warnanya. Warna pada kahut sigerbori adalah warna organik yang dihasilkan alami dari warna daun atau bunga yang dipindahkan ke media kain. Namun, Teknik hapazome yang digunakan dalam pembuatan kahut sigerbori bukan merupakan temuan baru/original, teknik ini merupakan teknik eco-printing dari Jepang. Meskipun demikian, di Lampung sendiri, kahut sigerbori dapat dikatakan produk yang baru diadopsi menjadi kerajinan khas masyarakat sekitar, sehingga dalam hal ini kahut sigerbori memiliki urgensi untuk dilindungi oleh HKI.

Menilik sudut pandang fisik terkait teknik pembuatan pewarnaan dan bahan material, kahut sigerbori tidak memiliki karakteristik khusus yang dinilai ekslusif. Terdapat beberapa produsen yang tersebar diseluruh Indonesia yang telah menghasilkan produk serupa, seperti Malang, Bali dan Pekalongan.Perlindungan hak kekayaan intelektual terhadap kahut sigerbori dapat melalui merek dagang, dikarenakan kahut sigerbori tidak masuk dalam komponen pada cakupan hak kekayaan intelektual lainnya.

Merek adalah suatu tanda yang dapat ditampilkan secara grafis untuk membedakan barang dan/atau jasa yang diproduksi oleh orang atau badan hukum dalam kegiatan perdagangan barang dan/atau jasa. Hak merek dapat diberikan pada pengusaha hasil karya kahut sigerbori sebagai tanda pengenal untuk membedakan hasil produksi yang dihasilkan individu atau badan tertentu dengan produsen lain; sebagai alat promosi dan jaminan atas mutu barang produksi. Hak merek terbagi atas hak atas merek dagang dan merek jasa, dalam hal ini kahut sigerbori bisa mendapatkan perlindungan atas hak merek dagangnya. Perlindungan hak merek bagi kahut sigerbori disebabkan oleh banyaknya pengrajin kain yang menggunakan teknik hapazome dan dapat berpotensi menimbulkan plagiarisme antar produsen. Oleh karena itu, untuk menjaga stabilitas produksi dan menghindari terjadinya sengketa, proses pendaftaran produk organik kain kahut sigerbori diperlukan agar karya tersebut mendapatkan perlindungan HKI secara legal.

\section{Pengaturan Haki di Indonesia Sebagai Opsi Perlindungan Produk Kain Organik Kahut Sigerbori}

Rezim merek dapat menjadi salah satu opsi Perlindungan HAKI bagi produk Kahut Sigerbori. Merek diatur dalam Undang-Undang Nomor 20 Tahun 2016 tentang Merek dan Indikasi Geografis dan Peraturan Pemerintah Nomor 22 Tahun 2018 tentang Pendaftaran Merek Internasional Berdasarkan Protokol Madrid yang dapat digunakan sebagai dasar hukum pendaftaran, pengenaan sanksi dan penyelesaian sengketa terkait merek. Oleh karena itu, diharapkan para produsen kain organik untuk mendaftarkan barang produksinya 
sehingga dilindungi oleh HKI. Pengaturan tentang merek dalam Undang Undang Merek dan Indikasi Geografis secara umum.

\section{Syarat Pendaftaran Merek}

Undang-Undang Nomor 20 Tahun 2016 Pasal 4 mengatur tentang syarat dan tata cara permohonan pendaftaran merek yang dijelaskan secara rinci, sebagai berikut:

1. Permohonan pendaftaran Merek diajukan oleh Pemohon atau Kuasanya kepada Menteri secara elektronik atau nonelektronik dalam bahasa Indonesia.

2. Dalam Permohonan sebagaimana dimaksud pada ayat (1) harus mencantumkan:
a) tanggal, bulan, dan tahun Permohonan;
b) nama lengkap, kewarganegaraan, dan alarnat Pemohon;
c) nama lengkap dan alamat Kuasa jika Permohonan diajukan melalui Kuasa;
d) warna jika Merek yang dimohonkan pendaftarannya menggunakan unsur warna;
e) nama negara dan tanggal permintaan Merek yang pertama kali dalam hal Permohonan diajukan dengan Hak Prioritas; dan
f) kelas barang dan/atau kelas jasa serta uraian jenis barang darr/atau jenis jasa.

\section{Permohonan ditandatangani Pemohon atau Kuasanya}

a) Permohonan sebagaimana dimaksud pacta ayat (1) dilampiri dengan label Merek dan bukti pembayaran biaya.

b) Biaya Permohonan pendaftaran Merek ditentukan per kelas barang dan/atau jasa.

c) Dalam hal Merek sebagaimana dimaksud pada ayat (4) berupa bentuk 3 (tiga) dirnensi, label Merek yang dilarnpirkan dalam bentuk karakteristik dari Merek tersebut.

d) Dalam hal Merek sebagaimana dimaksud pada ayat (4) berupa suara, label Merek yang dilampirkan berupa notasi dan rekaman suara.

e) Permohonan sebagaimana dimaksud pada ayat (1) wajib dilampiri dengan surat pernyataan kepemilikan Merek yang dimohonkan pendaftarannya.

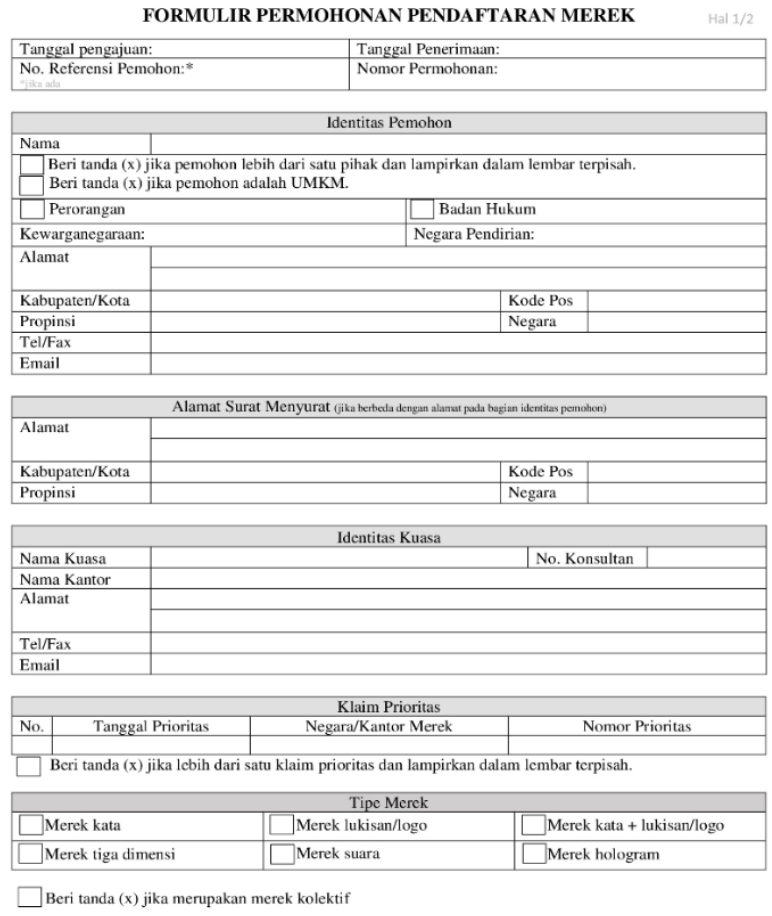

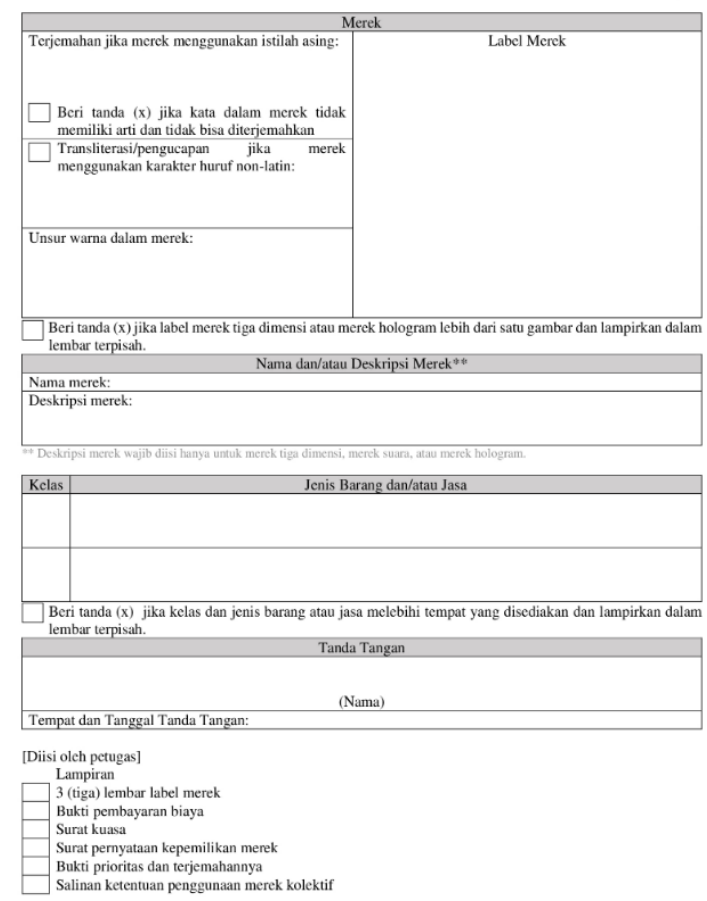



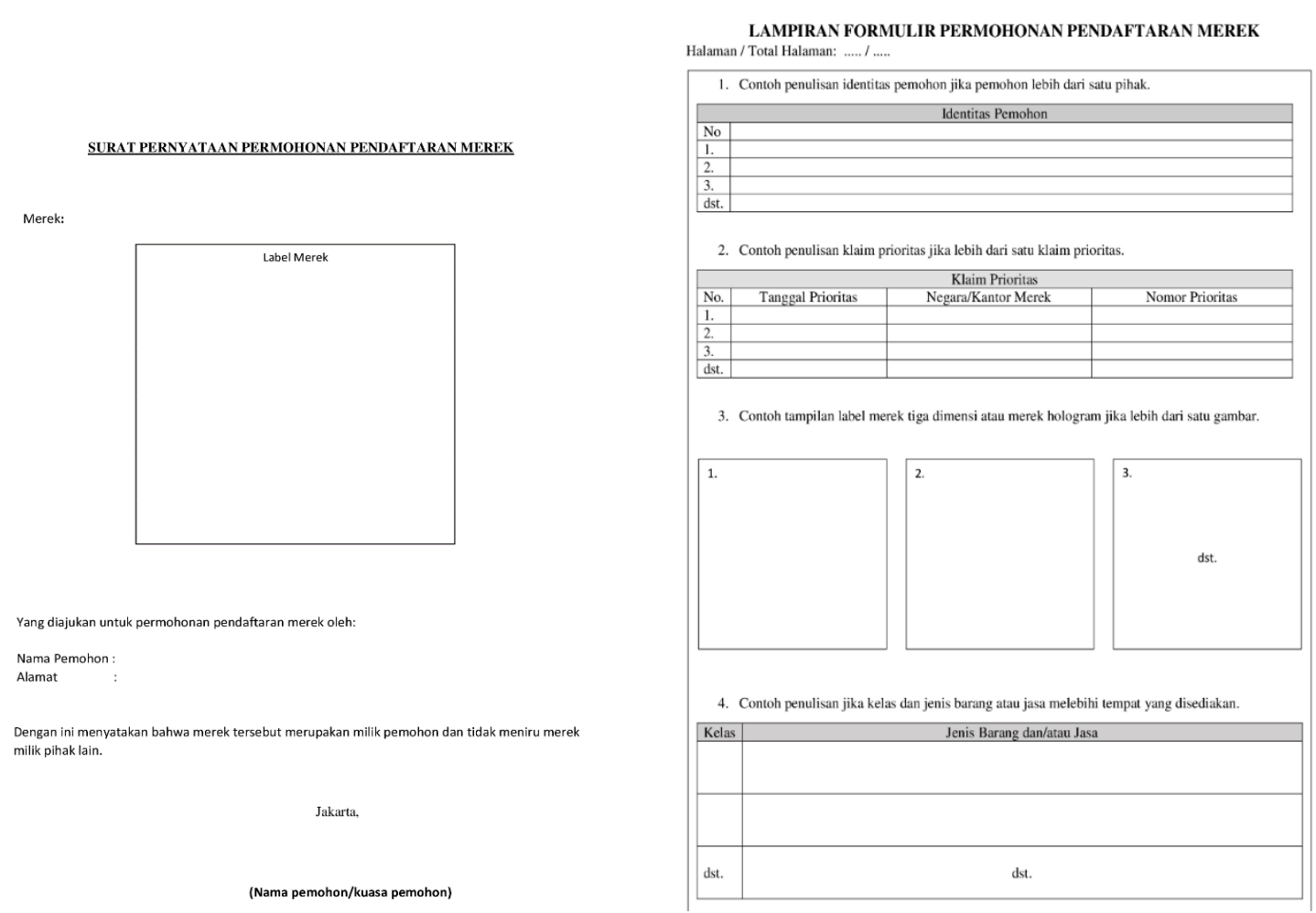

Gambar 1. Formulir Pendaftaran Merek

\section{Prosedur Permohonan Pendaftaran Merek}

Untuk dapat mendaftarkan merek, ada beberapa prosedur yang secara umum perlu diperhatikan.

Mengecek terlebih dahulu keberadaan merek terdaftar.

Sebelum melakukan pendaftaran merek, langkah pertama yang perlu dilakukan adalah mengecek terlebih dahulu keberadaan merek terdaftar melalui https://pdkiindonesia.dgip.go.id/. Hal ini perlu dilakukan untuk menghindari penolakan permohonan pendaftaran merek yang akan Anda ajukan atau sengketa merek lainnya apabila terdapat kesamaan dengan merek yang telah terdaftar.

\section{Permohonan Pendaftaran dapat dilakukan secara elektronik atau non-elektronik}

Permohonan secara elektronik dapat dilakukan melalui laman resmi Direktorat Jenderal, sedangkan permohonan secara non-elektronik dapat dilakukan melalui loket Direktorat Jenderal Kekayaan Intelektual (DJKI) melalui kantor wilayah terdekat. Namun hingga saat ini, permohonan secara elektronik hanya dapat dilakukan oleh Konsultan Kekayaan Intelektual terdaftar, di Kantor Wilayah Kementerian Hukum dan HAM dan Sentra HKI Perguruan Tinggi.

Untuk dapat melakukan permohonan pendaftaran merek, berikut beberapa persyaratan yang perlu Anda penuhi:

a. Mengisi formulir rangkap dua dalam bahasa Indonesia oleh Pemohon atau kuasanya kepada Menteri Hukum dan HAM.

Ketentuan terkait formulir dapat diunggah melalui Fomulir Permohonan Merek dengan memperhatikan keterangan klasifikasi kelas barang/jasa Harus melampirkan dokumen-dokumen, antara lain: Bukti pembayaran biaya permohonan; Informasi 
mengenai biaya dapat dilihat pada http://www.dgip.go.id/tarif-merek

b. Label merek sebanyak tiga lembar sesuai ketentuan dalam Fomulir Permohonan Merek Surat pernyataan kepemilikan merek; Surat kuasa, apabila permohonan diajukan melalui kuasa; Bukti prioritas, dalam hal menggunakan hak prioritas dan terjemahannya dalam bahasa Indonesia.

c. Pengumuman dalam Berita Resmi Merek

Apabila kelengkapan tersebut telah terpenuhi, maka terhadap permohonan akan diberikan tanggal penerimaan dan Menteri Hukum dan HAM akan mengumumkan permohonan merek dalam Berita Resmi Merek selama 2 (dua) bulan.

d. Penerbitan Sertifikat Merek

Apabila telah lolos pemeriksaan substantif dan tidak terdapat masalah dari permohonan pendaftaran merek yang diajukan, merek akan resmi terdaftar dengan bukti diterbitkannya sertifikat merek oleh Menteri Hukum dan HAM.

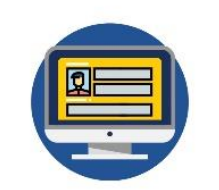

Registrasi akun merek.dgip.go.id

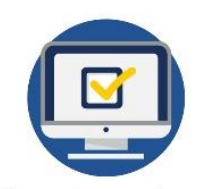

Permohonan kamu sudah kami terima

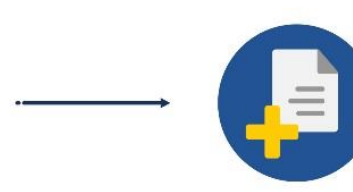

Klik tambah untuk membuat permohonan baru
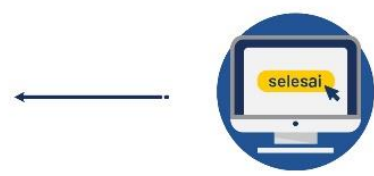

Jika dirasa semua sudah diisi dengan benar selanjutnya klik selesai

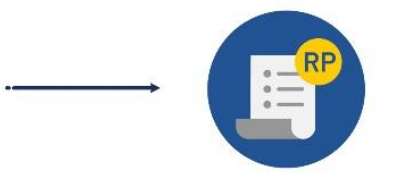

Pesan kode biling dengan mengisi tipe, jenis dan pilihan kelas
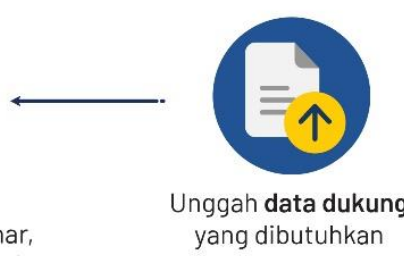

yang dibutuhkan

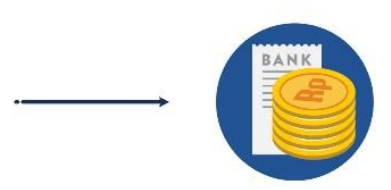

Lakukan pembayaran sesuai tagihan pada aplikasi SIMPAKI

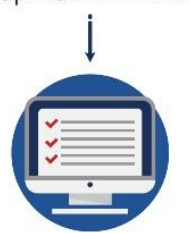

Isi seluruh formulir yang tersedia 


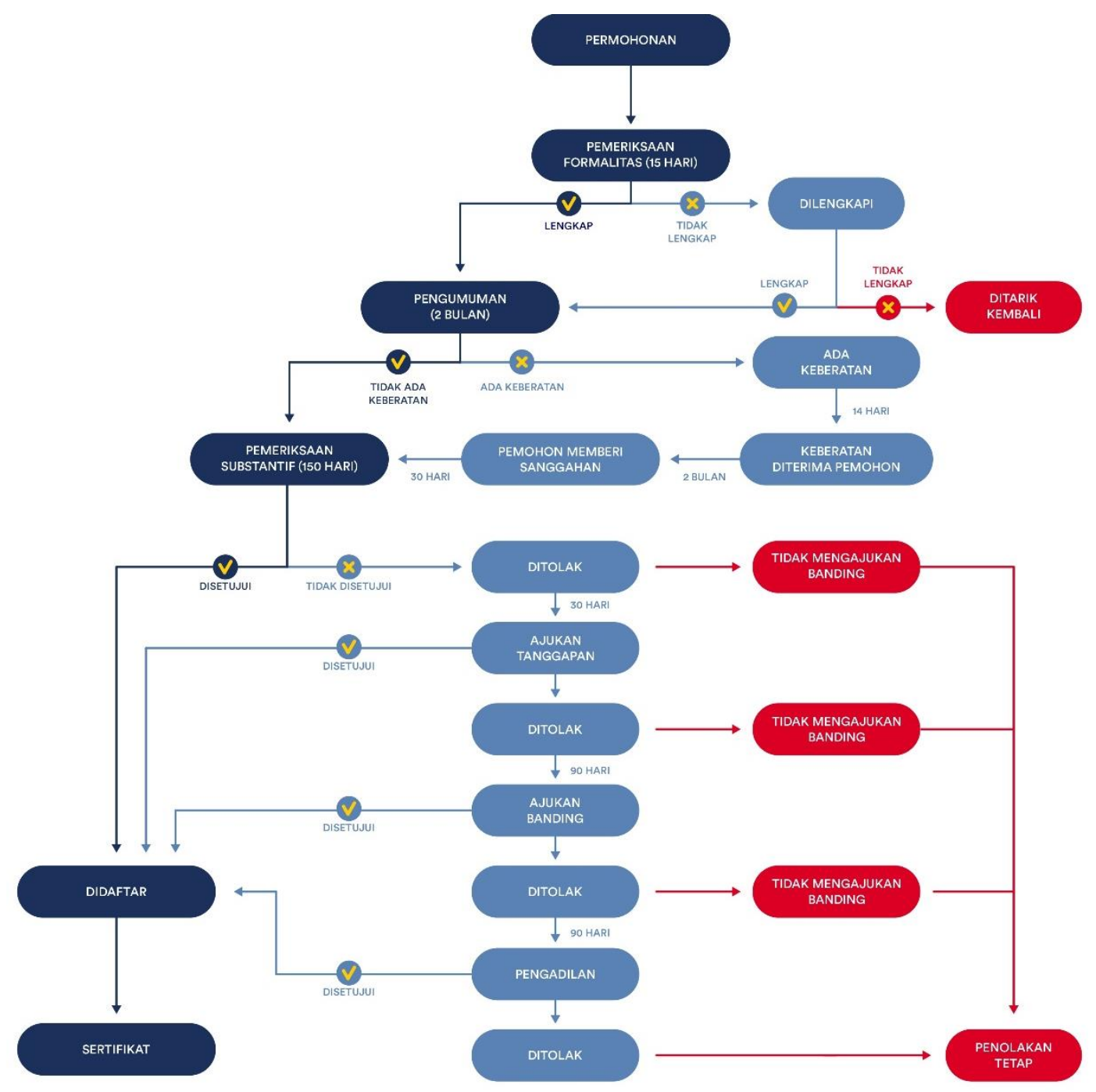

Gambar 3. Prosedur Permohonan Pendaftaran Merek Baru

Data Dukung yang diunggah:

a) Label Merek;

b) Tanda Tangan Pemohon;

c) Surat Keterangan UMK (jika pemohon merupakan usaha mikro atau usaha kecil).

UMKM ini sebenarnya dapat juga dilindungi dengan rezim hak cipta. Hak Cipta merupakan salah satu bagian dari kekayaan intelektual yang memiliki ruang lingkup objek dilindungi paling luas, karena mencakup ilmu pengetahuan, seni dan sastra yang di dalamnya mencakup pula program komputer. 


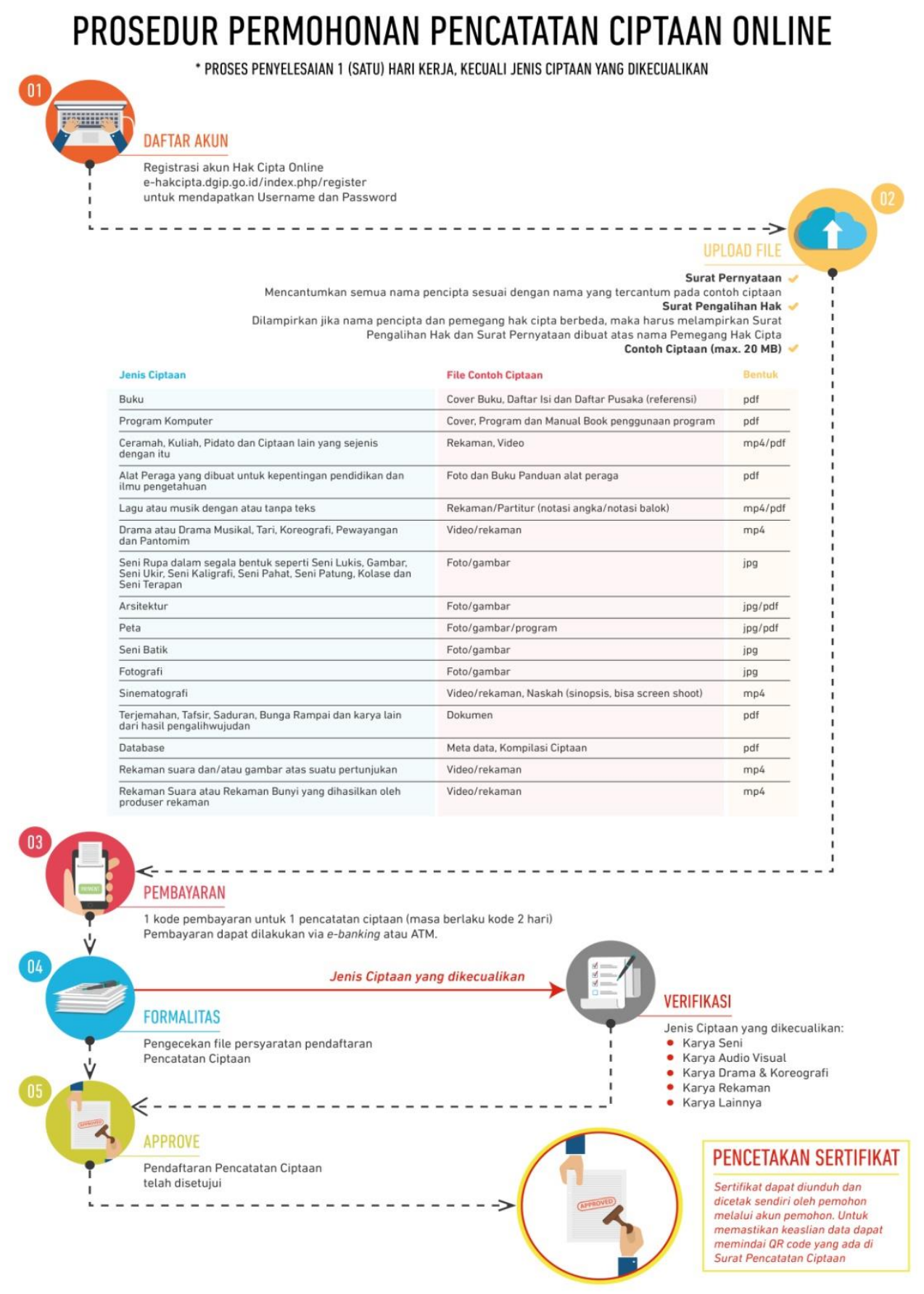

Gambar 4. Prosedur Permohonan Hak Cipta

\section{PELAKSANAAN FOCUS GROUP DISCUSSION}

Istilah kelompok diskusi terarah atau dikenal sebagai Focus Group Discussion (FGD) adalah diskusi terfokus dari suatu group untuk membahas suatu masalah tertentu, biasanya dalam suasana informal sehingga sedikit berbeda dengan seminar. FGD secara sederhana dapat didefinisikan sebagai suatu diskusi yang dilakukan secara sistematis dan terarah mengenai suatu isu atau masalah tertentu Jumlah pesertanya bervariasi antara 8-12 orang, dilaksanakan dengan panduan seorang moderator. FGD memberikan kemudahan dan peluang bagi peserta diskusi untuk menjalin keterbukaan, kepercayaan, dan memahami 
persepsi, sikap, serta pengalaman yang dimiliki oleh responden/pesertanya.

Pada pelaksanaan FGD Diseminasi Model Perlindungan Hak Kekayaan Intelektual Produk Kain Organik pada Komunitas Kahut Sigerbori di Labuhan Ratu Bandar Lampung dilakukan secara simultan on site dan on line pada saat pengabdian dan setelah pengabdian berlangsung. FGD diikuti dosen 5 dosen FH, 1 dosen FE, 2 Dosen MIPA ILKOM, 3 UMKM Produk Kreatif dan 1 NGO yang bergerak di bidang pemberdayaan perempuan. FGD dilakukan untuk mendiskusikan temuan pada saat survey dan setelah pelaksanaan, sebagaimana table berikut:

Tabel 1. Diskusi Hasil Temuan Survey

\begin{tabular}{|c|c|c|c|}
\hline NO & $\begin{array}{l}\text { Temuan sebelum } \\
\text { Pelaksanaan }\end{array}$ & $\begin{array}{c}\text { Temuan Pada Saat } \\
\text { Pelaksanaan }\end{array}$ & Hasil Diskusi Terarah (FGD) \\
\hline 1. & $\begin{array}{l}\text { Mitra telah mendengar } \\
\text { informasi berkenaan HAKI } \\
\text { tapi hanya mengingat istilah } \\
\text { paten. }\end{array}$ & $\begin{array}{l}\text { Mitra belum bisa } \\
\text { membedakan jenis } \\
\text { Perlindungan HAKI }\end{array}$ & $\begin{array}{l}\text { Mitra diberikan arahan untuk } \\
\text { fokus pada perlindungan } \\
\text { merek dan hak cipta }\end{array}$ \\
\hline 2. & $\begin{array}{l}\text { Tim merekomendasikan } \\
\text { Merek sebagai model } \\
\text { perlindungan HAKI bagi } \\
\text { mitra mengingat jenis } \\
\text { usahanya. }\end{array}$ & $\begin{array}{l}\text { Selain merek Mitra dapat } \\
\text { mengajukan Hak Cipta } \\
\text { untuk desain original Mitra. }\end{array}$ & $\begin{array}{l}\text { Tim mendiseminasikan } \\
\text { Perlindungan merek dan hak } \\
\text { cipta }\end{array}$ \\
\hline 3. & $\begin{array}{l}\text { Mitra membagikan } \\
\text { dokumentasi karya kreatif di } \\
\text { media sosial sehingga } \\
\text { terekspos secara langsung } \\
\text { ke publik }\end{array}$ & $\begin{array}{l}\text { Mitra tidak melakukan } \\
\text { dokumentasi dan } \\
\text { inventaris karya kreatif } \\
\text { mereka secara tertulis, } \\
\text { sistematis dan } \\
\text { berkelanjutan. }\end{array}$ & $\begin{array}{l}\text { Dokumentasi tertulis dan } \\
\text { inventaris bukti karya kreatif } \\
\text { diperlukan untuk membuat } \\
\text { uraian singkat dan data } \\
\text { dukung karya cipta }\end{array}$ \\
\hline 4. & $\begin{array}{l}\text { Tim pengabdian melakukan } \\
\text { diseminasi pada } 1 \text { mitra }\end{array}$ & $\begin{array}{l}\text { Diseminasi diikuti oleh } 2 \\
\text { UMKM lain bahkan apabila } \\
\text { tidak terkendala COVID } 19 \\
\text { bisa diikuti beberapa mitra } \\
\text { sekaligus }\end{array}$ & $\begin{array}{l}\text { Mitra terutama yang bergerak } \\
\text { di bidang usaha kreatif untuk } \\
\text { tertarik dan memerlukan } \\
\text { informasi berkaitan HAKI. }\end{array}$ \\
\hline 5 & $\begin{array}{l}\text { Pengabdian ditujukan untuk } \\
\text { diseminasi informasi HAKI }\end{array}$ & $\begin{array}{l}\text { Pengabdian tentang HAKI } \\
\text { ternyata tidak hanya cukup } \\
\text { untuk didiseminasikan } \\
\text { tetapi ada kegiatan } \\
\text { lanjutan }\end{array}$ & $\begin{array}{l}\text { Direkomendasikan untuk } \\
\text { melakukan kegiatan lanjutan } \\
\text { berupa klinik, workshop } \\
\text { ataupun konsultasi berkenaan } \\
\text { dengan HAKI. }\end{array}$ \\
\hline
\end{tabular}

\section{KESIMPULAN}

1. Mitra mengetahui informasi tentang HAKI tetapi belum bisa membedakan jenis perlindungan HAKI.

2. Perlindungan HAKI yang direkomendasikan untuk mitra adalah hak cipta dan merek

3. Kegiatan diseminasi HAKI perlu ditindaklanjuti dengan kegiatan klinik, workshop dan konsultasi berkenaan HAKI bagi mitra yang lebih beragam

\section{DAFTAR PUSTAKA}

[1] Dagne, T. (2010). Law and Policy on Intellectual Property, Traditional Knowledge and Development: Legally Protecting Creativity and Collective Rights in Traditional Knowledge-Based. Retrieved from https://papers.ssrn.com/sol3/papers.cfm?abstract_id=1600293

[2] Gervais, D. D. J. (2003). The TRIPS agreement: drafting history and analysis. sweet \& maxwell.

[3] GRAIN. (2000). FOR A FULL REVIEW OF TRIPS 27.3(b) An update on where developing countries stand with the push to patent life at WTO GRAIN March 2000 Agreement on Trade-Related Aspects of 
Intellectual Property Rights (TRIPS). Barcelona. Retrieved from https://www.grain.org/article/entries/39for-a-full-review-of-trips-27-3-b

[4] Josling, T. (2006). The war on terroir: Geographical indications as a transatlantic trade conflict. Journal of Agricultural Economics, 57(3), 337-363. https://doi.org/10.1111/j.1477-9552.2006.00075.x

[5] Marie-Vivien, D. (2010). The Role of the State in the Protection of Geographical Indications: From Disengagement in France/Europe to Significant Involvement in India. The Journal of World Intellectual Property, 13(2), 121-147. https://doi.org/10.1111/j.1747-1796.2009.00375.x

[6] Septiono, S. (2009). Geographical Indication Protection and Indonesia's Geographical Indication Potential. Jakarta.

[7] South-East Asia IPR SME Helpdesk. (2016). Intellectual Property and the ASEAN Economic Community (AEC). Ho Chi Min: EU. Retrieved from http://www.southeastasiaiprhelpdesk.eu/sites/default/files/publications/AEC-English.pdf

[8] Wierma Putri, R. (2015). Protect Traditional Knowledge of Indigenous People with Geographical Indication (Rule of Law and Hak Asasi Manusia). Jakarta. Retrieved from http://www.pusham.uii.ac.id/index.php?page=Istarticledl\&lang=en\&idx=120

[9] WTO. (2001). WTO | intellectual property (TRIPS) - Reviews, Article 27.3b, traditional knowledge, biodiversity - background. Retrieved March 27, 2018, from https://www.wto.org/english/tratop_e/trips_e/art27_3b_background_e.htm 